Meta

Journal des traducteurs

Translators' Journal

\title{
Construction of Conceptual Frames during Simultaneous Interpreting
}

\section{Hiroyuki Ishizuka}

Volume 60, numéro 2, août 2015

$60^{\mathrm{e}}$ anniversaire. Les horizons de la traduction : retour vers le futur $60^{\text {th }}$ Anniversary. Translation's Horizons: Back to the Future

60mo aniversario. Los horizontes de la traducción: regreso al futuro

URI : https://id.erudit.org/iderudit/1032892ar

DOI : https://doi.org/10.7202/1032892ar

Aller au sommaire du numéro

Éditeur(s)

Les Presses de l’Université de Montréal

ISSN

0026-0452 (imprimé)

1492-1421 (numérique)

Découvrir la revue

Citer ce document

Ishizuka, H. (2015). Construction of Conceptual Frames during Simultaneous Interpreting. Meta, 60(2), 341-341. https://doi.org/10.7202/1032892ar d'utilisation que vous pouvez consulter en ligne. 


\title{
Construction of Conceptual Frames during Simultaneous Interpreting
}

\author{
Hiroyuki IshizuKa \\ Hiroshima Shudo University, Hiroshima, Japan \\ hishizuk@shudo-u.ac.jp
}

This study explores the status of mental representations constructed by an interpreter. The study's main focus is the interpreter's construction of conceptual frames from the source speech.

Before an interpreter can produce a translated message in the target language, the message expressed in the source language must be comprehended, although it is not completely comprehended during the early part of the discourse. In this process, the interpreter constructs schemas of the message (e.g., theme-rheme structure) at discourse level. This study aims to explore the interpreter's meaning construction, to assess the non-linguistic status of mental representations and provide an explicit description of it.

This study focuses on the following issues:

- Construction of conceptual frames in the interpreter's discourse processing

- Retention of the conceptual frames during the interpreter's performance

- The non-linguistic status of the conceptual frames

- The role of the conceptual frames in the interpreter's production.

Since interpreting is not simply code switching from one language into another, looking at the actual interpreting performance, various differences can be identified between the source text and the target text. Such differences provide empirical clues to exploring the cognitive operations during simultaneous interpreting.

This study is based on a simultaneous interpreting transcript (English to Japanese) of a Japanese TV program. The juxtaposition of source and target text reflects the temporal correspondence between the source speaker's utterance and the interpreter's production. By analysing the transcript, the development of the interpreter's mental representations is traced.

Hiroyuki Ishizuka obtained his PhD in interpreting studies (2013) from Kobe City University of Foreign Studies and is associate professor at Hiroshima Shudo University. His research interest is construction of (non-linguistic) concepts during simultaneous interpreting explored through linguistic clues in the transcriptions of interpreting performances. He recently published "Doujitsuyaku-sha-ni-yoru shieki-teki-jishou-kouzou-no haaku" [Construction of a causal event structure by a simultaneous interpreter] in Interpreting and Translation Studies (2010) and "Repetitive translation and conceptual processing in SI" in Interpreting and Translation Studies (2012). 